\title{
Nitrate Measurement
}

National Cancer Institute

\section{Source}

National Cancer Institute. Nitrate Measurement. NCI Thesaurus. Code C161352.

The determination of the amount of nitrate present in a sample. 